\title{
A EFETIVIDADE DAS DECISÕES CONDENATÓRIAS DA CORTE INTERAMERICANA DE DIREITOS HUMANOS NO ESTADO

\author{
BRASILEIRO: uma análise das medidas impostas nas decisões e
}

\author{
do seu cumprimento
}

\author{
Luana Mengue Rodrigues ${ }^{1}$ \\ Caroline Dimuro Bender D'Ávila²
}

Resumo: O presente artigo foi confeccionado com o objetivo de analisar a efetividade das decisões condenatórias proferidas pela Corte Interamericana de Direitos Humanos em face do Estado brasileiro. Foram examinados, para tanto, todos os quatro casos julgados em desfavor do país, assim como a postura da Administração Pública diante das determinações impostas nas sentenças internacionais. O trabalho foi desenvolvido com base em pesquisa bibliográfica documental, com caráter exploratório e descritivo, bem como através de coleta de dados executada por meio de leis, artigos jurídicos, tratados internacionais, consulta junto aos sites institucionais do Sistema Interamericano, entre outros. Diante da pesquisa realizada verificou-se que, dentre as quatro condenações existentes, desde que voluntariamente, o Brasil sujeitou-se à jurisdição da Corte, apenas uma foi cumprida integralmente pelo país. As demais se encontram pendentes, principalmente, de investigação e punição dos responsáveis pela violação dos direitos humanos ocorrida em cada caso específico. Por outro lado, para tornar o procedimento de cumprimento das sentenças proferidas pelo órgão judicial internacional mais célere e efetivo no Estado brasileiro, constatouse ser extremamente importante a criação de um mecanismo interno específico, capaz de honrar com as disposições internacionais e, assim, dar cumprimento integral a todas as medidas impostas nas sentenças proferidas pela Corte Interamericana em face do Estado brasileiro.

Palavras-chave: Estado brasileiro. Corte Interamericana. Direitos humanos. Sentenças.

Abstract: This article was prepared with the objective of analyzing the effectiveness of the conviction decisions handed down by the Inter - American Court of Human Rights in relation to the Brazilian State. For this purpose, all four cases judged to be unfavorable to the country were examined, as well as the attitude of the Public Administration front to determinations imposed in international judgments. The work was developed based on documental bibliographic research, with an exploratory and

${ }^{1}$ Acadêmica do curso de direito da UNICNEC.

2 Prof ${ }^{\mathrm{a}}$. Me. do Curso de Direito da UNICNEC.

DIREITO, CULTURA E CIDADANIA

Osório, v. 7, n. 1, 2017

DOI 10.26547/2236.3734.2017.1.170 
descriptive character, as well as through data collection performed through laws, legal articles, international treaties, and surveys with the institutional sites of the InterAmerican System, among others. In view of the research carried out, it was verified that, among four existing convictions, since voluntarily, the Brazil submitted to the Court jurisdiction, only one was fulfilled complied with by the country. The others are pending, mainly, for investigation and punishment of those responsible for the violation of human rights occurred in each specific case. On the other hand, to render the procedure for complying with the judgments rendered by international judicial body faster and more effective in the Brazilian State, it was found to be extremely important to create a specific internal inland mechanism capable of complying with international provisions, and then, to comply fully to all the measures imposed in the judgments of the Inter-American Court in face to the Brazilian State.

Key words: Brazilian state. Inter-American Court. Human Rights. Judgments.

\section{INTRODUÇÃO}

O Sistema Interamericano de Proteção dos Direitos Humanos - encarregado pela proteção dos direitos humanos em âmbito regional - é representado, principalmente, pela Convenção Americana de Direitos Humanos, do ano de 1969, a qual foi responsável por instituir a Comissão e a Corte Interamericana de Direitos Humanos. Destarte, para que um Estado Parte seja submetido à jurisdição da Corte Interamericana de Direitos Humanos, deve ter aderido à sua competência ${ }^{3}$. No plano contencioso, a Corte tem competência para julgar casos em que um Estado Parte tenha violado dispositivo da Convenção Americana de Direitos Humanos e, na hipótese de ser reconhecida a violação, para determinar, ao Estado infrator, a adoção de providências necessárias à recomposição do direito desrespeitado4.

\footnotetext{
${ }^{3}$ Art. 62.1: Todo Estado Parte pode, no momento do depósito do seu instrumento de ratificação desta Convenção ou de adesão a ela, ou em qualquer momento posterior, declarar que reconhece como obrigatória, de pleno direito e sem convenção especial, a competência da Corte em todos os casos relativos à interpretação ou aplicação desta Convenção. (ORGANIZAÇÃO DOS ESTADOS AMERICANOS. Convenção Americana de Direitos Humanos. Disponível em: https://www.cidh.oas.org/basicos/portugues/c.convencao_americana.htm. Acesso em: 04 nov. 2016). ${ }^{4}$ PIOVESAN, Flávia. Direitos humanos e o direito constitucional internacional. 11. ed. rev. e atual. São Paulo: Saraiva, 2010. p. 271.
} 
O Estado brasileiro reconheceu a competência da Corte Interamericana de Direitos Humanos no ano de 1998, através do Decreto Legislativo no 895, já tendo recebido condenações por meio das sentenças internacionais. No entanto, a despeito desse reconhecimento, não há, no ordenamento jurídico brasileiro, uma legislação específica que discipline o modo de cumprimento das sentenças proferidas pelo órgão judicial internacional em face do país, dever imposto ao Estado brasileiro6.

Com efeito, examinar a questão relacionada à interligação entre os sistemas jurídicos interno e internacional, analisando as formas de cumprimento das decisões emanadas pelo órgão jurisdicional do Sistema Interamericano de Proteção dos Direitos Humanos, com o fim de visualizar uma sociedade que possa ver seus direitos protegidos, trata-se de ação fundamental. Trazer à baila tal discussão, sem a pretensão de esgotar o assunto, é extremamente relevante, uma vez que lançar o problema relacionado à efetividade das decisões internacionais já é um progresso para que, futuramente, seja criado um mecanismo interno para observância e cumprimento, pelo Brasil, das determinações impostas pela Corte Interamericana de Direitos Humanos. Desse modo, aqueles que sofreram atos violadores dos seus direitos humanos, ou seus familiares, quando praticados pelo Estado brasileiro, poderão alcançar uma célere e justa reparação governamental.

Para tanto, será analisada a legitimidade das decisões emanadas pela Corte Interamericana de Direitos Humanos em desfavor do Estado brasileiro, tendo em vista a sujeição voluntária do país à sua jurisdição, bem como o conceito de soberania que rege as relações internacionais; serão identificados, também, todos os casos julgados

\footnotetext{
${ }^{5}$ BRASIL. Decreto n. 89, de 3 de dezembro de 1998. Aprova a solicitação de reconhecimento da competência obrigatória da Corte Interamericana de Direitos Humanos em todos os casos relativos à interpretação ou aplicação da Convenção Americana de Direitos Humanos para fatos ocorridos a partir do reconhecimento, de acordo com o previsto no parágrafo primeiro do art. 62 daquele instrumento internacional. Disponível em: http://www2.camara.leg.br/legin/fed/decleg/1998/decretolegislativo-893-dezembro-1998-369634-publicacaooriginal-1-pl.html. Acesso em: 04 nov. 2016.

${ }^{6}$ Art. 2: Se o exercício dos direitos e liberdades mencionados no artigo 1 ainda não estiver garantido por disposições legislativas ou de outra natureza, os Estados Partes comprometem-se a adotar, de acordo com as suas normas constitucionais e com as disposições desta Convenção, as medidas legislativas ou de outra natureza que forem necessárias para tornar efetivos tais direitos e liberdades. (ORGANIZAÇÃO DOS ESTADOS AMERICANOS. Convenção Americana de Direitos Humanos. Disponível em: https://www.cidh.oas.org/basicos/portugues/c.convencao_americana.htm. Acesso em: 04 nov. 2016).
} 
pela Corte Interamericana de Direitos Humanos nos quais o Brasil foi condenado, as medidas impostas nas decisões, assim como quais sentenças foram cumpridas voluntariamente pelo país e sua repercussão no âmbito interno; e, por fim, será realizado um estudo acerca da implementação das decisões proferidas pela Corte Interamericana de Direitos Humanos, propondo alternativas para tornar 0 procedimento de cumprimento das sentenças internacionais mais célere e efetivo no país. 


\section{O SISTEMA INTERAMERICANO DE PROTEÇÃO DOS DIREITOS HUMANOS}

Para que se possa compreender acerca dos objetivos do presente artigo será apresentada, nesse tópico, a criação e a estrutura da Organização dos Estados Americanos - OEA -, responsável pela proteção dos direitos humanos no âmbito regional interamericano. Ademais, será demonstrada a organização e o funcionamento da Corte Interamericana de Direitos Humanos, instituída por meio da Convenção Americana de Direitos Humanos, um dos principais tratados do Sistema Interamericano de Proteção dos Direitos Humanos.

\subsection{Organização dos Estados Americanos: criação e estrutura}

Até meados do século $X X$, os direitos humanos eram protegidos apenas pelos sistemas jurídicos nacionais ${ }^{7}$. De fato, a solidificação da proteção dos direitos humanos internacionalmente deu-se em decorrência da Segunda Guerra Mundial, ou seja, através de um movimento muito recente na história ${ }^{8}$. Com efeito, do mesmo modo que a Segunda Guerra Mundial significou a interrupção da proteção aos direitos humanos, o período pós-guerra buscou a reconstrução desses direitos ${ }^{9}$. Foi então que, em 1945, com a criação da Organização das Nações Unidas, surgiu um sistema global de proteção aos direitos humanos ${ }^{10}$.

Todavia, além dos instrumentos relativos à proteção global dos direitos humanos, surgiram, também, instrumentos de proteção regional, os quais são representados pelos sistemas europeu, americano e africano. Sinale-se, nesse sentido, que ambos os sistemas, global e regional, coexistem e são

\footnotetext{
${ }^{7}$ AMARAL JUNIOR, Alberto do. Curso de Direito Internacional Público. 4. ed. São Paulo: Atlas S.A, 2013. p. 508.

${ }^{8}$ PIOVESAN, Flávia. Direitos humanos e o direito constitucional internacional. 11. ed. rev. e atual. São Paulo: Saraiva, 2010. p. 121.

9lbidem, p. 122.

10MAZZUOLI, Valério de Oliveira. Curso de Direito Internacional Público. 5. ed. rev., atual. e ampl. São Paulo: Revista dos Tribunais, 2011. p. 815.
} 
complementares ${ }^{11}$, ou seja, ambos os sistemas são inspirados pelo mesmo objetivo, a proteção dos direitos humanos, da paz e da segurança internacionais ${ }^{12}$.

Alberto do Amaral Júnior enfatiza que:

A proteção dos direitos humanos suscitou, no plano regional, a elaboração de formas sofisticadas de solução de controvérsias destinadas a assegurar a eficácia dos direitos e liberdades garantidos internacionalmente ${ }^{13}$.

Cada sistema regional de proteção dos direitos humanos possui um ordenamento jurídico próprio $^{14}$, sendo que a eles cabe a observância e devido tratamento dos problemas específicos de cada região. Não obstante as diferenças organizacionais das instituições, o objetivo almejado é o mesmo, de articular a cooperação regional, principalmente no que tange à proteção dos direitos humanos. Por conta disso, diversos tratados foram celebrados por estas instituições, a fim de proteger referidos direitos ${ }^{15}$.

O Sistema Interamericano de Proteção dos Direitos Humanos, objeto do presente trabalho, encontra-se inserido no âmbito da Organização dos Estados Americanos - OEA ${ }^{16}$. Sua criação remonta ao ano de 1948, em Bogotá, na Colômbia, quando os estados interamericanos adotaram a Carta da Organização dos Estados Americanos, a Declaração Americana dos Direitos e Deveres do Homem e o Convênio Econômico de Bogotá ${ }^{17}$. Conforme dispõe o art. 4ํํ da Carta, são membros da Organização os Estados que a ratificaram, sendo que o Estado brasileiro está entre os 21 Estados fundadores que participaram da criação da OEA ${ }^{18}$.

\footnotetext{
${ }^{11}$ lbidem.

12AMARAL JUNIOR, op. cit., p. 529.

${ }^{13}$ AMARAL JUNIOR, Alberto do. Curso de Direito Internacional Público. 4. ed. São Paulo: Atlas S.A, 2013. p. 530.

${ }^{14}$ PIOVESAN, Flávia. Direitos humanos e o direito constitucional internacional. 11. ed. rev. e atual. São Paulo: Saraiva, 2010. p. 253.

${ }^{15}$ MAZZUOLI, Valério de Oliveira. Curso de Direito Internacional Público. 5. ed. rev., atual. e ampl. São Paulo: Revista dos Tribunais, 2011. p. 641.

${ }^{16}$ CULLETON, Alfredo; BRAGATO, Fernanda Frizzo; FAJARDO, Sinara Porto. Curso de Direitos Humanos. São Leopoldo: Unissinos, 2009. p. 130.

17 MAZZUOLI, op. cit., p. 651.

${ }^{18}$ Ibidem, p. 654.
} 
A constituição da Organização deu-se depois de longas e pacíficas negociações ocorridas desde a primeira Conferência Internacional dos Países Americanos, nos anos 1889 e $1890^{19}$. Assim, a partir do estatuto institucional dado à Organização, o que antes era a Associação de Nações Americanas, passou a ser um organismo regional das Nações Unidas ${ }^{20}$.

Segundo Valério de Oliveira Mazzuoli "a Carta da Organização dos Estados Americanos é um tratado internacional multilateral aberto instituidor de organização internacional"21 e, segundo o art. 1ำ da Carta, sua criação objetivou garantir aos Estados membros "uma ordem de paz e de justiça, para promover sua solidariedade, intensificar sua colaboração e defender sua soberania, sua integridade territorial e sua independência [...]"22. Nesse mesmo sentido, Friedmann Wendpap e Rosane Kolotelo assim dispõem:

A finalidade da Organização é a manutenção da paz no Continente, prevenindo o surgimento de litígios entre os Estados americanos e propiciando segurança coletiva no caso de agressão vinda de outro Continente $[\ldots]^{23}$.

A Organização dos Estados Americanos compõe-se de quatro principais diplomas normativos: a Carta da Organização dos Estados Americanos; a Declaração Americana dos Direitos e Deveres do Homem; a Convenção Americana de Direitos Humanos; e o Protocolo relativo aos direitos sociais e econômicos (San Salvador) ${ }^{24}$. Além disso, suas funções são exercidas através dos órgãos que a compõe, quais

${ }^{19} \mathrm{ACCIOLY}$, Hildebrando; SILVA, G. E. do Nascimento E; CASELLA, Paulo Borba. Manual de Direito Internacional Público. 18. ed. São Paulo: Saraiva, 2010. p. 456.

20lbidem, p. 458.

${ }^{21}$ MAZZUOLI, Valério de Oliveira. Curso de Direito Internacional Público. 5. ed. rev., atual. e ampl. São Paulo: Revista dos Tribunais, 2011. p. 652.

${ }^{22}$ ORGANIZAÇÃO DOS ESTADOS AMERICANOS. Carta da Organização dos Estados Americanos. Disponível em: http://www.oas.org/dil/port/tratados_A41_Carta_da_Organiza\%C3\%A7\%C3\%A3o_dos_Estados_Americanos.htm. Acesso em: 04 nov. $20 \overline{16}$.

${ }^{23}$ WENDPAP, Friedmann; Kolotelo, Rosane. Direito Internacional. Rio de Janeiro: Elsevier, 2007. p. 160.

${ }^{24}$ ACCIOLY, Hildebrando; SILVA, G. E. do Nascimento E; CASELLA, Paulo Borba. Manual de Direito Internacional Público. 18. ed. São Paulo: Saraiva, 2010. p. 479. 
sejam: a Assembleia Geral, a Reunião de Consulta dos Ministros das Relações Exteriores, os Conselhos, a Comissão Jurídica Interamericana, a Comissão Interamericana de Direitos Humanos e a Secretaria Geral ${ }^{25}$.

\subsection{Corte Interamericana de Direitos Humanos: organização e funcionamento}

Conforme dito anteriormente, cada um dos sistemas regionais possui um aparato jurídico específico. No caso do Sistema Interamericano, o principal instrumento é a Convenção Americana de Direitos Humanos, também denominada Pacto de San José da Costa Rica, do ano de 1969, haja vista ter sido a responsável pela instituição da Comissão e da Corte Interamericana de Direitos Humanos ${ }^{26}$. Sinale-se, ainda, que em 1988 a Organização dos Estados Americanos adotou um protocolo à Convenção relativo a direitos sociais, econômicos e culturais, o qual recebeu a denominação de San Salvador e que entrou em vigor internacionalmente em $1999^{27}$.

Somente os Estados pertencentes à Organização dos Estados Americanos podem adotar a Convenção ${ }^{28}$. O Estado brasileiro, por sua vez, a ratificou no ano de 1992, através do Decreto no 678²9. Ratificou também, em 1999, o Protocolo de San Salvador, por meio do Decreto $\mathrm{n}^{0} 3.321^{30}$.

De forma resumida, a Convenção possui duas repartições. A primeira informa um rol de direitos civis e políticos, tais como o direito à vida, direito à liberdade, direito de não ser submetido à escravidão, etc. A segunda trata de enumerar os meios pelos quais a proteção de tais direitos pode ser alcançada ${ }^{31}$.

${ }^{25}$ MAZZUOLI, op. cit., 656.

${ }^{26}$ PIOVESAN, Flávia. Direitos humanos e o direito constitucional internacional. 11. ed. rev. e atual. São Paulo: Saraiva, 2010. p. 251.

27PIOVESAN, Flávia. Direitos humanos e o direito constitucional internacional. 11. ed. rev. e atual. São Paulo: Saraiva, 2010. p. 257.

${ }^{28}$ Ibidem, p. 256.

${ }^{29}$ MAZZUOLI, Valério de Oliveira. Curso de Direito Internacional Público. 5. ed. rev., atual. e ampl. São Paulo: Revista dos Tribunais, 2011. p. 882

30 lbidem, p. 883.

${ }^{31}$ lbidem, p. 882. 
A Comissão Interamericana de Direitos Humanos, além de se tratar de um órgão da Organização dos Estados Americanos, é também órgão da Convenção Americana de Direitos Humanos. A Corte Interamericana de Direitos Humanos, no entanto, é órgão apenas desta última ${ }^{32}$, sendo que possui competência consultiva no que diz respeito à interpretação da Convenção e demais tratados internacionais sobre a proteção dos direitos humanos - e contenciosa - relativa à solução de controvérsias $^{33}$. Com sede em São José, na Costa Rica, a Corte Interamericana de Direitos Humanos compõe-se por sete juízes pertencentes aos Estados membros da OEA, todos com nacionalidades diferentes ${ }^{34}$.

A competência contenciosa da Corte Interamericana de Direitos Humanos alcança apenas os Estados Partes da Convenção que tenham aderido à sua competência, sendo que, em caso de violação à Convenção Americana de Direitos Humanos, a Corte disporá sobre a adoção de medidas de recomposição do direito violado, inclusive com indenizações pecuniárias à vitima ${ }^{35}$. Nesse sentido, cumpre referir que as sentenças proferidas pela Corte possuem caráter definitivo e irrecorrível ${ }^{36}$. Observa-se, igualmente, que apenas os Estados Partes da Convenção, bem como a Comissão Interamericana de Direitos Humanos possuem legitimidade para apresentar algum caso à Corte ${ }^{37}$.

O meio de proteção previsto na Convenção Americana de Direitos Humanos pode ser entendido da seguinte maneira: a vítima da violação dos direitos humanos pode peticionar à Comissão Interamericana de Direitos Humanos que apreciará a admissibilidade e o mérito do caso exposto. Sendo admissível e possuindo fundamento, com a constatação de possível violação aos direitos humanos, a

\footnotetext{
${ }^{32}$ Ibidem, p. 884.

${ }^{33}$ PIOVESAN, op. cit., p. 266.

${ }^{34}$ MAZZUOLI, op. cit., p. 889.

${ }^{35}$ PIOVESAN, op. cit., p. 271.

${ }^{36}$ MAZZUOLI, Valério de Oliveira. Curso de Direito Internacional Público. 5. ed. rev., atual. e ampl. São Paulo: Revista dos Tribunais, 2011. p. 891.

${ }^{37}$ Art. 61.1: Somente os Estados Partes e a Comissão têm direito de submeter caso à decisão da Corte. (ORGANIZAÇÃO DOS ESTADOS AMERICANOS. Convenção Americana de Direitos Humanos. Disponível em: https://www.cidh.oas.org/basicos/portugues/c.convencao_americana.htm. Acesso em: 04 nov. 2016).
} 
Comissão poderá propor ação junto à Corte Interamericana de Direitos Humanos em face do Estado infrator, para eventual responsabilização internacional, situação em que é assegurada a ampla defesa e o contraditório. Ao final, a Corte imporá sua sentença ${ }^{38}$.

Nesse viés, para melhor entender sobre a legitimidade das decisões proferidas pela Corte Interamericana de Direitos Humanos, mediante a sujeição voluntária dos Estados à sua jurisdição, importante enfatizar os ensinamentos de Valério de Oliveira Mazzuoli no que tange ao conceito de soberania que rege as relações internacionais. Segundo o doutrinador, o governo de estado possui duas funções, uma no plano interno, outra no plano internacional. Na primeira, é responsável por administrar o país, enquanto que na segunda é responsável por participar das relações internacionais do Estado ${ }^{39}$. Enfatiza, outrossim, que Estado soberano é aquele que:

[...] não reconhece nenhum poder superior capaz de ordenar o exercício de suas competências internas, cedendo apenas a essa intangibilidade para se pôr ao lado de seus homólogos na realização do ideal comum de construção da ordem internacional, e na medida necessária para que tal ordem se desenvolva e se torne a gestora dos interesses comuns das várias nações do planeta ${ }^{40}$.

Acerca do mesmo tema, Renata Campetti Amaral informa que "governo soberano é aquele não subordinado, onde o Estado consegue operar sua capacidade de ação no plano internacional em nível igualitário aos demais Estados da comunidade internacional" 41 . Segundo a doutrinadora, a ideia de soberania:

[...] refere-se à união de estados autônomos na qual há a cessão de suas soberanias para um centro de poder único (União Federal), mantendo-se, todavia, um grau variável de autonomia ${ }^{42}$.

\footnotetext{
${ }^{38}$ ACCIOLY, Hildebrando; SILVA, G. E. do Nascimento E; CASELLA, Paulo Borba. Manual de Direito Internacional Público. 18. ed. São Paulo: Saraiva, 2010. p. 479.

${ }^{39}$ MAZZUOLI, op. cit., p. 439.

${ }^{4}$ olbidem.

${ }^{41}$ AMARAL, Renata Campetti. Direito Internacional Público e Privado. 6. ed. Porto Alegre: Verbo Jurídico, 2010. p. 29.

${ }^{42}$ lbidem.
} 
Pois bem, enquanto Estado soberano, o Brasil era livre para aderir ou não a competência contenciosa da Corte Interamericana de Direitos Humanos. Isso porque, conforme dito anteriormente, "[...] a competência contenciosa da Corte Interamericana é limitada aos Estados-partes da Convenção que reconheçam expressamente a sua jurisdição"43, ou seja, o Brasil, assim como os demais Estados que ratificaram a Convenção Americana, somente serão julgados pela Corte se espontaneamente aceitarem a sua competência contenciosa ${ }^{44}$.

No caso do Estado brasileiro, a competência contenciosa da Corte Interamericana de Direitos Humanos foi reconhecida voluntariamente através do Decreto Legislativo nº 89, do ano de 1998, o qual determina que o país poderá ser demandado perante a Corte com relação as denuncias que acusem violações de direitos humanos acontecidas após esse reconhecimento ${ }^{45}$. Pois bem, considerando que "a Corte não relata casos e não faz qualquer tipo de recomendação no exercício de sua competência contenciosa, mas profere sentenças, que segundo o Pacto de San José são definitivas e inapeláveis" 46 , bem como a sujeição voluntária do país a jurisdição da Corte Interamericana, tem-se que as sentenças internacionais proferidas em desfavor do Estado brasileiro são legítimas e devem sim ser obrigatoriamente cumpridas em âmbito interno pelo país. Inclusive, o art. 68.1 da Convenção Americana de Direitos Humanos informa que "os Estados-partes na Convenção comprometemse a cumprir a decisão da Corte em todo caso em que forem partes" 47 .

${ }^{43}$ MAZZUOLI, Valério de Oliveira. Curso de Direito Internacional Público. 5. ed. rev., atual. e ampl. São Paulo: Revista dos Tribunais, 2011. p. 890.

${ }^{44}$ Art. 62.1: Todo Estado Parte pode, no momento do depósito do seu instrumento de ratificação desta Convenção ou de adesão a ela, ou em qualquer momento posterior, declarar que reconhece como obrigatória, de pleno direito e sem convenção especial, a competência da Corte em todos os casos relativos à interpretação ou aplicação desta Convenção. (ORGANIZAÇÃO DOS ESTADOS AMERICANOS. Convenção Americana de Direitos Humanos. Disponível em: https://www.cidh.oas.org/basicos/portugues/c.convencao_americana.htm. Acesso em: 04 nov. 2016). ${ }^{45} \mathrm{MAZZUOLI}$, op. cit.

${ }^{46}$ lbidem, p. 891.

${ }^{47}$ ORGANIZAÇÃO DOS ESTADOS AMERICANOS. Convenção Americana de Direitos Humanos. Disponível em: https://www.cidh.oas.org/basicos/portugues/c.convencao_americana.htm. Acesso em: 04 nov. 2016. 


\section{CONDENAÇÕES PROFERIDAS PELA CORTE INTERAMERICANA DE DIREITOS HUMANOS EM FACE DO ESTADO BRASILEIRO}

No presente título, a partir de uma pesquisa realizada junto ao site da Corte Interamericana de Direitos Humanos, será apresentada uma relação de todas as decisões condenatórias proferias pela Corte Interamericana de Direitos Humanos em face do Estado brasileiro, bem como uma descrição detalhada de todas as medidas impostas nas sentenças internacionais.

\subsection{A relação dos casos julgados em desfavor do Brasil}

Tendo o Estado brasileiro reconhecido a competência da Corte Interamericana de Direitos Humanos no ano de 1998, através do Decreto Legislativo oㅡ 89, já recebeu condenações por meio das sentenças internacionais. Insta salientar, porque importante, que existem alguns requisitos a serem cumpridos para que uma demanda possa ser julgada pela Corte Interamericana de Direitos Humanos, os quais estão previstos no art. 46 da Convenção Americana de Direitos Humanos ${ }^{48}$, assim como no Regulamento da Corte Interamericana de Direitos Humanos ${ }^{49}$.

A primeira condenação do Estado brasileiro perante a Corte ocorreu no caso "Ximenes Lopes", cuja sentença foi proferida na data de 04/07/2006. Em síntese, buscava-se a responsabilização internacional do país por maus tratos e consequente

\footnotetext{
${ }^{48}$ Art. 46.1: Para que uma petição ou comunicação apresentada de acordo com os artigos 44 ou 45 seja admitida pela Comissão, será necessário: a. que hajam sido interpostos e esgotados os recursos da jurisdição interna, de acordo com os princípios de direito internacional geralmente reconhecidos; b. que seja apresentada dentro do prazo de seis meses, a partir da data em que o presumido prejudicado em seus direitos tenha sido notificado da decisão definitiva; c. que a matéria da petição ou comunicação não esteja pendente de outro processo de solução internacional; e d. que, no caso do artigo 44, a petição contenha o nome, a nacionalidade, a profissão, o domicílio e a assinatura da pessoa ou pessoas ou do representante legal da entidade que submeter a petição. (ORGANIZAÇÃO DOS ESTADOS AMERICANOS. Convenção Americana de Direitos Humanos. Disponível em: https://www.cidh.oas.org/basicos/portugues/c.convencao_americana.htm. Acesso em: 04 nov. 2016).

${ }^{49} \mathrm{CORTE}$ INTERAMERICANA DE DIREITOS HUMANOS. $\mathbf{R}$ egulamento da Corte Interamericana de Direitos Humanos. Disponível em: https://www.cidh.oas.org/basicos/portugues/Viejos/w.Regulamento.Corte.htm. Acesso em: 04 nov. 2016.
} 
morte de Damião Ximenes Lopes, ocorrida em uma instituição mental vinculada ao Sistema Único de Saúde, bem como a investigação e devida punição dos responsáveis ${ }^{50}$. Nesta situação, o caso foi julgado pela Corte Interamericana de Direitos Humanos por conta da demora do Poder Judiciário Brasileiro, mais precisamente o Estado do Ceará, em resolver o ocorrido ${ }^{51}$. De fato, a omissão quanto à investigação e posterior punição dos agentes, bem como às garantias judiciais, acabaram por violar dispositivos da Convenção, principalmente os artigos 4, 5, 8 e 25, que significam, respectivamente, o direito à vida, à integridade física, às garantias judiciais e à proteção judicial ${ }^{52}$.

Passados mais de três anos da primeira condenação, na data de 20/11/2009, o Brasil foi punido pela segunda vez, cujo caso tornou-se conhecido como "Escher e outros". Nesse processo, a responsabilização do Estado brasileiro foi pleiteada por possível interceptação, monitoramento e divulgação das conversas telefônicas, pela Polícia Militar do Estado do Paraná, de Arlei José Escher, Dalton Luciano de Vargas, Delfino José Becker, Pedro Alves Cabral e Celso Aghinoni (membros da Cooperativa Agrícola de Conciliação Avante - COANA e da Associação comunitária de Trabalhadores Rurais - ADECON ${ }^{53}$. Segundo denunciou a Comissão Interamericana de Direitos Humanos, o Brasil teria violado os artigos 8.1, 11, 16 e 25 da Convenção Americana de Direitos Humanos, ou seja, garantias judiciais, proteção da honra e da dignidade, liberdade de associação e proteção judicial, respectivamente, situação que fez o caso ser levado à Corte para julgamento ${ }^{54}$.

${ }^{50}$ CORTE INTERAMERICANA DE DIREITOS HUMANOS. Dados técnicos caso "Ximenes Lopes": Disponível http://www.corteidh.or.cr/cf/Jurisprudencia2/ficha_tecnica.cfm?nld_Ficha=319\&lang=en. Acesso em: 04 nov. 2016.

${ }^{51}$ ACCIOLY, Hildebrando; SILVA, G. E. do Nascimento E; CASELLA, Paulo Borba. Manual de Direito Internacional Público. 18. ed. São Paulo: Saraiva, 2010. p. 480.

${ }^{52}$ MAZZUOLI, Valério de Oliveira. Curso de Direito Internacional Público. 5. ed. rev., atual. e ampl. São Paulo: Revista dos Tribunais, 2011. p. 898.

${ }^{53}$ CORTE INTERAMERICANA DE DIREITOS HUMANOS. Dados técnicos caso "Escher e outros". Disponível http://www.corteidh.or.cr/cf/Jurisprudencia2/ficha_tecnica.cfm?nld_Ficha=277\&lang=en. Acesso em: 04 nov. 2016.

${ }^{54}$ GORCZEVSKI, Clovis; LEAL, Mônia Clarissa Heninng. Constitucionalismo Contemporâneo: Desafios e Perspectivas. Curitiba: Multideia, 2012. p. 154. 
"Garibaldi", com sentença proferida em 23/09/2009, foi o terceiro caso a ser julgado pela Corte Interamericana de Direitos Humanos em desfavor do Estado brasileiro. Buscava-se, com a ação, a responsabilização do país em decorrência de não ter investigado e punido o assassinato de Sétimo Garibaldi, que ocorreu na execução de um despejo extrajudicial no Estado do Paraná, situação que ocasionou a violação de dispositivos da Convenção Americana de Direitos Humanos, por uma série de irregularidades tanto na investigação policial quanto judicial dos acontecimentos $^{55}$. Sétimo Garibaldi era um dos trabalhadores sem terra que ocupavam uma fazenda no Estado do Paraná. Restou demonstrado, no caso, que a violação de direitos humanos de trabalhadores sem terra, classe deveras vulnerável, conforme dispôs a própria Corte, é uma das mais importantes causas de hostilidade no campo no Brasil, sobretudo porque a impunidade possibilita a violação contínua a esses direitos. A demora injustificada em investigar adequadamente o caso, que foi considerada pela Corte como o erro mais grave praticado pelo Estado brasileiro, demonstrou a evidente parcialidade e o descaso das autoridades estatais quanto ao tratamento da violência no campo $^{56}$. O país teria recebido recomendações da Comissão Interamericana de Direitos Humanos antes de o caso ser levado ao órgão jurisdicional interamericano. No entanto, deixou de tomar qualquer providência, situação que originou a denúncia perante a Corte Interamericana de Direitos Humanos ${ }^{57}$.

Por fim, no quinto e último caso julgado em desfavor do Estado brasileiro, intitulado como "Gomes Lund e outros (Guerrilha do Araguaia)", cujo acórdão foi proferido em 24/11/2010, buscou-se a responsabilização do país pela falta de investigação quanto ao desaparecimento forçado dos membros pertencentes à

${ }^{55}$ CORTE INTERAMERICANA DE DIREITOS HUMANOS. Dados técnicos caso "Garibaldi". Disponível em: http://www.corteidh.or.cr/cf/Jurisprudencia2/ficha_tecnica.cfm?nld_Ficha=282\&lang=en. Acesso em: 04 nov. 2016.

${ }^{56}$ CORTE INTERAMERICANA DE DIREITOS HUMANOS. Sentença caso "Garibaldi”. Disponível em: http://www.corteidh.or.cr/docs/casos/articulos/seriec_203_por.pdf. Acesso em: 04 nov. 2016.

${ }^{57 G O R C Z E V S K I}$, Clovis; LEAL, Mônia Clarissa Heninng. Constitucionalismo Contemporâneo: Desafios e Perspectivas. Curitiba: Multideia, 2012. p. 154. 
Guerrilha do Araguaia, que ocorreu entre os anos de 1972 a $1975^{58}$. A petição fora submetida à Comissão pelo CEJIL - Centro pela Justiça e o Direito Internacional - e pela "Human Rigths Watch Americas", em nome das pessoas desaparecidas e de seus parentes. O Estado brasileiro deixou de cumprir recomendações emitidas pela Comissão Interamericana de Direitos Humanos, sendo que a demanda foi promovida perante a Corte para a responsabilização do país pela tortura, detenção e desaparecimento de 70 pessoas ligadas às operações do exército brasileiro ${ }^{59}$.

\subsection{Medidas impostas pela Corte nas decisões condenatórias proferidas contra o Brasil}

No site da Corte Interamericana de Direitos Humanos há uma relação de todos os casos contenciosos listados no item anterior, nos quais o Brasil foi condenado por ter sido considerado violador dos direitos humanos invocados nas demandas propostas. São disponibilizadas, também, as decisões relacionadas a exceções preliminares, assim como o mérito das sentenças, com as medidas que foram impostas ao país ${ }^{60}$.

No caso "Ximenes Lopes", o Estado brasileiro foi condenado por violação dos direitos à vida e à integridade pessoal consagrados nos artigos 4.1, 5.1 e 5.2 da Convenção Americana de Direitos Humanos. Os Juízes da Corte Interamericana decidiram, por unanimidade, condenar o Estado brasileiro às seguintes sanções: a) garantir a celeridade da justiça interna no que tange à investigação e consequente punição dos responsáveis pela tortura e morte de Damião Ximenes Lopes; b) publicar no Diário Oficial e também em jornal de grande circulação, uma só vez, em até seis

\footnotetext{
${ }^{58}$ CORTE INTERAMERICANA DE DIREITOS HUMANOS. Dados técnicos caso "Gomes Lund e outros (Guerrilha do Araguaia)". Disponível em: http://www.corteidh.or.cr/cf/Jurisprudencia2/ficha_tecnica.cfm?nld_Ficha=342\&lang=en. Acesso em: 04 nov. 2016.

${ }^{59}$ GORCZEVSKI, Clovis; LEAL, Mônia Clarissa Heninng. Constitucionalismo Contemporâneo: Desafios e Perspectivas. Curitiba: Multideia, 2012. p. 154.

${ }^{60}$ CORTE INTERAMERICANA DE DIREITOS HUMANOS. Decisões e Julgamentos. Disponível em: http://www.corteidh.or.cr/cf/Jurisprudencia2/index.cfm?lang=en. Acesso em: 04 nov. 2016.
} 
meses, o Capítulo VII da respectiva sentença internacional, que informa os fatos provados no caso, bem como sua parte resolutiva; c) prosseguir no desenvolvimento de programas de formação para as pessoas que trabalham na área da saúde, inclusive as vinculadas ao atendimento de saúde mental; d) pagar em dinheiro e no prazo de um ano, a título de indenização por danos morais, o valor de US $\$ 1.500,00$ (mil e quinhentos dólares dos Estados Unidos da América) para a mãe de Damião Ximenes Lopes, Sra. Albertina Viana Lopes, e a quantia de US\$10.000,00 (dez mil dólares dos Estados Unidos da América) para a irmã, Sra. Irene Ximenes Lopes Miranda; d) pagar em dinheiro e no prazo de um ano aos pais e irmãos de Damião Ximenes Lopes, a título de indenização por dano imaterial, o valor de US\$50.000,00 (cinquenta mil dólares dos Estados Unidos da América), bem como as quantias individuais de US\$30.000,00 (trinta mil dólares dos Estados Unidos da América) para a Sra. Albertina Viana Lopes (mãe), US\$10.000,00 (dez mil dólares dos Estados Unidos da América) ao Sr. Francisco Leopoldino Lopes (pai), US\$25.000,00 (vinte e cinco mil dólares dos Estados Unidos da América) a Sra. Irene Ximenes Lopes Miranda (irmã) e US\$10.000,00 (dez mil dólares dos Estados Unidos da América) ao Sr. Cosme Ximenes Lopes (irmão); e) pagar no prazo de um ano e em dinheiro, a título de custas e gastos relativos aos trâmites internos e ao processo no âmbito internacional, o valor de US\$10.000.00 (dez mil dólares dos Estados Unidos da América), que deverá ser entregue a Sra. Albertina Viana Lopes (mãe); f) apresentar à Corte, no prazo de um ano, um relatório sobre as medidas adotadas para a execução das determinações ${ }^{61}$.

Ao proferir sentença no caso "Escher e outros", a Corte Interamericana declarou que o Estado brasileiro violou as disposições contidas nos artigos 8.1, 11, 16 e 25 da Convenção Americana de Direitos Humanos, quais sejam, respectivamente, o direito à vida privada, à honra, à reputação, o direito à liberdade de associação, bem como as garantias judiciais e a proteção judicial. Os Juízes decidiram, por

${ }^{61}$ CORTE INTERAMERICANA DE DIREITOS HUMANOS. Sentença caso “Damião Ximenes Lopes”. Disponível em: http://www.corteidh.or.cr/docs/casos/articulos/seriec_149_por.pdf. Acesso em: 04 nov. 2016. 
unanimidade, condenar o Estado brasileiro as seguintes penalidades: a) pagar a cada vítima, a título de dano imaterial e no prazo de um ano, o valor de US $\$ 20.000,00$ (vinte mil dólares dos Estados Unidos da América); b) publicar no Diário Oficial, em outro jornal de grande circulação nacional e em um jornal de vasta circulação do Estado do Paraná, uma só vez e no prazo de seis meses, a página de rosto, os capítulos I, VI a XI, bem como a parte resolutiva da respectiva sentença internacional; c) publicar integralmente, no prazo de dois meses, a sentença em um site oficial da União Federal e também do Estado do Paraná; d) investigar todos os fatos que geraram as violações declaradas na sentença; e) pagar às vitimas, a título de restituição de custas e gastos e no prazo de um ano, o montante de US $\$ 10.000,00$ (dez mil dólares dos Estados Unidos da América); f) apresentar à Corte, no prazo de um ano, um relatório sobre as medidas adotadas para o cumprimento integral da sentença proferida ${ }^{62}$.

Com relação ao caso "Garibaldi", a sentença declarou que o Estado brasileiro violou os direitos contidos nos artigos 8.1 e 25.1 da Convenção Americana de Direitos Humanos, ou seja, as garantias judiciais e a proteção judicial, em prejuízo dos familiares de Sétimo Garibaldi. Os juízes da Corte Interamericana decidiram, por unanimidade, punir o país em: a) publicar uma vez e em até seis meses no Diário Oficial, em outro jornal de grande circulação nacional, e também em um jornal de grande visibilidade no Estado do Paraná, a página de rosto, os Capítulos I, VI e VII, assim como a parte resolutiva da respectiva sentença internacional; b) publicar em até dois meses, integralmente e por um ano, a sentença proferida pela Corte junto a um site oficial da União e também do Estado do Paraná; c) identificar, julgar e, se necessário, punir os autores do assassinato de Sétimo Garibaldi, conduzindo de forma eficiente e em prazo coerente o inquérito policial e eventual processo a ser proposto para atingir referida determinação; d) investigar e, eventualmente, condenar as possíveis faltas funcionais que podem ter praticado os funcionários públicos a cargo

${ }^{62}$ CORTE INTERAMERICANA DE DIREITOS HUMANOS. Sentença caso “Escher e outros". Disponível em: http://www.corteidh.or.cr/docs/casos/articulos/seriec_200_por.pdf. Acesso em: 04 nov. 2016. 
do inquérito; e) pagar em um ano a título de dano material e imaterial, o valor total de US\$ 51.000,00 (cinquenta mil dólares dos Estados Unidos da América) em favor de Iracema Garibaldi, e US\$20.000,00 (vinte mil dólares dos Estados Unidos da América) aos demais familiares de Sétimo Garibaldi, quais sejam Alexandre Garibaldi, Darsônia Garibaldi, Fernando Garibaldi, Itamar Garibaldi, Itacir Garibaldi e Vanderlei Garibaldi; f) pagar em um ano a título de custas e gastos, o valor de US\$ 8.000,00 (oito mil dólares dos Estados Unidos da América) a Iracema Garibaldi; g) apresentar à Corte, no prazo de um ano, um relatório sobre as medidas adotadas para o cumprimento integral da sentença proferida ${ }^{63}$.

Por fim, a sentença do caso "Gomes Lund e outros (Guerrilha do Araguaia)" declarou que a Lei de Anistia brasileira é conflitante com a Convenção Americana de Direitos Humanos, não podendo servir como empecilho para a apuração dos fatos do caso em análise, bem como para o reconhecimento e consequente sanção dos responsáveis; que o Estado possui responsabilidade quanto ao desaparecimento forçado dos membros da Guerrilha do Araguaia e, à vista disso, pela violação dos artigos 3, 4, 5, 7, 8.1 e 25.1 da Convenção da Convenção Americana de Direitos Humanos, que representam, respectivamente, o direito ao reconhecimento da personalidade jurídica, à vida, à integridade pessoal, à liberdade pessoal, garantias judiciais e proteção judicial; que o Estado brasileiro descumpriu o disposto no artigo 2 da Convenção Americana de Direitos Humanos, ou seja, o dever de adotar disposições de direito interno para se adequar à Convenção, sobretudo pela interpretação e aplicação que foi dada à Lei de Anistia no que diz respeito as graves violações aos direitos humanos; que o Estado brasileiro é responsável pelo descumprimento do artigo 13 da Convenção Americana de Direitos Humanos, tendo violado, portanto, o direito à liberdade de pensamento e de expressão. Os Juízes da Corte decidiram, por unanimidade, condenar o Estado brasileiro as seguintes sanções: a) comandar junto à jurisdição ordinária, ativamente, a investigação penal quanto aos acontecimentos do feito em análise, a fim de desvendá-los, determinando

${ }^{63}$ CORTE INTERAMERICANA DE DIREITOS HUMANOS. Sentença caso “Garibaldi”. Disponível em: http://www.corteidh.or.cr/docs/casos/articulos/seriec_203_por.pdf. Acesso em: 04 nov. 2016. 
as consequentes sanções penais aos responsáveis e demais efeitos que a lei preveja; b) executar todo o empenho possível para definir a localização das vítimas desaparecidas e, eventualmente, reconhecer e entregar os restos mortais aos seus familiares; c) disponibilizar o tratamento médico, psiquiátrico ou psicológico as vítimas que solicitem e, caso necessário, pagar-lhes o valor correspondente; d) realizar as publicações da sentença nos locais e formas estipuladas no parágrafo 273 do documento (Diário Oficial, outro de ampla circulação nacional, etc.); e) realizar uma solenidade pública de reconhecimento da responsabilidade internacional no que tange aos fatos do presente feito; f) desenvolver cursos de capacitação e implantar, em um prazo adequado, um projeto obrigatório e duradouro relativamente a direitos humanos, o qual deve ser destinado a todas as categorias das Forças Armadas; g) empregar, em um prazo adequado, as medidas que se fizerem necessárias para que se torne típico o crime de desaparecimento forçado de pessoas, de acordo com os preceitos interamericanos, prazo em que devem ser adotados procedimentos que assegurem o satisfatório julgamento, e caso se faça necessário, sanção dos responsáveis por desaparecimento forçado, o que deve ser feito por meio dos instrumentos internos; $h$ ) permanecer avançando nas diligências de busca, coordenação e veiculação de qualquer informação referente à Guerrilha do Araguaia, bem como no que tange a ofensa aos direitos humanos verificada no período de regime militar; i) pagar a título de indenização por danos imateriais o valor de US\$45.000,00 (quarenta e cinco mil dólares dos Estados Unidos da América) para cada familiar direto das vítimas e de US $\$ 15.000,00$ (quinze mil dólares dos Estados Unidos da América) para cada familiar não direto; j) pagar o valor de US\$3.000,00 (três mil dólares dos Estados Unidos da América) a título de dano material em favor de cada um dos familiares das vítimas (elencados na sentença); k) pagar a título de custas e gastos o valor de US\$5.000,00 (cinco mil dólares dos Estados Unidos da América) para o Grupo Tortura Nunca Mais, US\$ 5.000,00 (cinco mil dólares dos Estados Unidos da América) para a Comissão de Familiares de Mortos e Desaparecidos Políticos de São Paulo e US\$35.000,00 (trinta e cinco mil dólares dos Estados Unidos da América) em favor do Centro pela Justiça e o Direito Internacional; I) convocar em um jornal nacional e um regional, durante 24 
(vinte e quatro) meses, os familiares das pessoas indicadas pela Comissão Interamericana de Direitos Humanos como supostas vítimas do presente caso (parágrafo 19 da sentença), cujo reconhecimento dessa condição não foi feita pelo país, a fim de que tragam provas que permitam ao Estado identificá-las e assim considera-las vítimas na forma da Lei no 9.140/1995; m) autorizar que, dentro do prazo de seis meses, os familiares das vítimas que não solicitaram indenização nos termos da Lei no 9.140/95, o façam, se assim desejarem; n) apresentar à Corte, no prazo de um ano, um relatório sobre as medidas adotadas para o cumprimento integral da sentença proferida 64 .

\section{A EFETIVIDADE DAS SENTENÇAS DA CORTE INTERAMERICANA DE DIREITOS HUMANOS NO SISTEMA INTERNO BRASILEIRO}

Como forma de analisar o comprometimento do Estado brasileiro com as decisões emanadas pela Corte Interamericana de Direitos Humanos em seu desfavor, bem como contribuir para a celeridade da conclusão dos casos, mediante o cumprimento integral das determinações impostas nas sentenças, demonstrar-se-á, nesta seção, quais sentenças foram cumpridas voluntariamente pelo país, ainda que parcialmente, com a análise da sua repercussão no âmbito interno, assim como serão apresentadas algumas propostas para agilizar o cumprimento das sentenças internacionais internamente.

\subsection{Sentenças cumpridas voluntariamente pelo Estado brasileiro e sua repercussão no âmbito interno}

${ }^{64}$ CORTE INTERAMERICANA DE DIREITOS HUMANOS. Sentença caso "Gomes Lund e outros do Araguaia)". 
Além da relação de todas as sentenças julgadas pela Corte Interamericana de Direitos Humanos em desfavor do Estado brasileiro, o site institucional do Tribunal também disponibiliza um link para monitoramento do cumprimento das decisões pelo país. No caso "Ximenes Lopes", a Corte já emitiu três pareceres, sendo o último datado de 17/05/2010. Relativamente aos casos "Escher e outros" e "Garibaldi", a Corte pronunciou-se apenas duas vezes, sendo as últimas em 19/06/2012 e 20/02/2012, respectivamente. Quanto ao cumprimento da sentença do caso "Gomes Lund e outros" (Guerrilha do Araguaia), a Corte emanou somente um parecer, o qual é datado de 17/10/201465.

Destarte, muito embora a sentença do caso "Ximenes Lopes" tenha sido proferida no ano de 2006, o Estado brasileiro ainda não logrou êxito em cumprir integralmente as determinações impostas na sentença pela Corte Interamericana de Direitos Humanos. De fato, no último parecer de cumprimento de sentença disponibilizado, o Tribunal informou que o procedimento de monitoramento seria mantido em aberto pela falta de cumprimento, pelo Estado, de alguns deveres estabelecidos na decisão, quais sejam: a) garantir a celeridade do processo interno para investigação e, se for o caso, sanção dos responsáveis pelos fatos que deram ensejo à condenação do país na presente demanda; b) e prosseguir no desenvolvimento de programas de formação para a área médica e todas as demais vinculadas ao atendimento de saúde mental, sobretudo com enfoque nos princípios que norteiam o trato com as pessoas. Por conseguinte, excluindo-se da sentença de mérito, reparação e custas, as medidas ainda não efetivadas pelo país, possível verificar o cumprimento espontâneo da maioria das condenações, ou seja, as de publicações da sentença internacional e de pagamentos a título de danos morais,

\footnotetext{
${ }^{65}$ CORTE INTERAMERICANA DE DIREITOS HUMANOS. Monitoramento Cumprimento de Sentença. 
danos imateriais, bem como custas e gastos atinentes aos procedimentos internos e ao processo na esfera internacional66.

No caso "Escher e outros", contudo, o cumprimento da sentença deu-se de maneira mais célere e efetiva. De fato, com sentença proferida no ano de 2009, o documento de supervisão de cumprimento da decisão datado de 2012 deu por concluído o feito, ante o fato de o Estado brasileiro ter dado cumprimento integral a todos os pontos resolutivos da sentença internacional ${ }^{67}$.

O caso "Garibaldi", cuja sentença também foi proferida no ano de 2009, encontra-se pendente de encerramento por falta de cumprimento, pelo país, de apenas uma determinação imposta na sentença. Efetivamente, o Estado brasileiro cumpriu integralmente as obrigações destinadas ao pagamento de indenização por danos materiais e imateriais aos familiares da vítima, bem como restituiu os valores inerentes a custas e gastos. Do mesmo modo, cumpriu com as determinações de publicação da respectiva sentença e procedeu nas investigações administrativas dos funcionários públicos a cargo do inquérito, razão pela qual a Corte igualmente determinou o arquivamento desse último ponto resolutivo da decisão. Noutro giro, resta pendente a determinação para que o Brasil proceda eficazmente na investigação e, se for o caso, punição dos responsáveis pela morte de Sétimo Garibaldi68.

O caso "Gomes Lund e outros (Guerrilha do Araguaia)" trata-se da sentença mais complexa e recente na qual o Brasil sofreu uma condenação. Isso porque, conforme dito alhures, a decisão foi proferida no ano de 2010 e impôs diversas determinações ao Estado. À vista disso, na supervisão de cumprimento de sentença emitida no ano de 2014, é possível perceber que o país ainda não deu total

${ }^{66}$ CORTE INTERAMERICANA DE DIREITOS HUMANOS. Supervisão de Cumprimento de Sentença caso "Ximenes Lopes". Disponível em: http://www.corteidh.or.cr/docs/supervisiones/ximenes_17_05_10_\%20por.pdf. Acesso em: 04 nov. 2016.

${ }^{67}$ CORTE INTERAMERICANA DE DIREITOS HUMANOS. Supervisão de Cumprimento de Sentença caso "Escher e outros". Disponível em: http://www.corteidh.or.cr/docs/supervisiones/escher_19_06_12_por.pdf. Acesso em: 04 nov. 2016.

${ }^{68}$ CORTE INTERAMERICANA DE DIREITOS HUMANOS. Supervisão de Cumprimento de Sentença caso "Garibaldi". Disponível em: http://www.corteidh.or.cr/docs/supervisiones/garibaldi_20_02_12_por.pdf. Acesso em: 04 nov. 2016. 
cumprimento aos pontos da decisão. Até o presente momento o Estado brasileiro realizou apenas, de forma efetiva, as publicações da sentença internacional e concedeu o prazo estabelecido na decisão para que os familiares das vítimas que não haviam requerido indenização nos termos da Lei no 9.140/95 o fizessem. Bem assim, cumpriu apenas parcialmente sua obrigação de busca de informações sobre a Guerrilha do Araguaia e quanto às violações dos direitos humanos acontecidas durante o regime militar, de pagar as quantias destinadas às indenizações por dano material, imaterial e para restituição de custas e gastos, bem como de convocar os familiares das pessoas não reconhecidas pelo país como vítimas no presente caso, para aportarem provas que permitam sua identificação. Noutro giro, o Estado brasileiro ainda continua aplicando a Lei de Anistia em determinadas decisões judiciais internamente, situação que vem dificultando a investigação e eventual punição dos responsáveis ${ }^{69}$. Inclusive, algum tempo antes de ser proferida a sentença internacional no presente caso, em sede de Arguição de Descumprimento de Preceito Fundamental - ADPF, o STF apreciou a Lei de Anistia Brasileira e, por 7 votos contra 2, decidiu em sentido contrário ao da Corte Interamericana de Direitos Humanos, ou seja, pela constitucionalidade da Lei analisada, o que demonstra o descaso do órgão máximo de deliberação no Brasil com o órgão jurisdicional internacional ${ }^{70}$. Logo, a Corte mantém em aberto a supervisão de todos os pontos da sentença que foram cumpridos apenas parcialmente ou que sequer foram cumpridos pelo Estado brasileiro, os quais representam grande parte das determinações impostas na decisão ${ }^{71}$.

${ }^{69}$ CORTE INTERAMERICANA DE DIREITOS HUMANOS. Supervisão de Cumprimento de Sentença caso "Gomes Lund e outros (Guerrilha do Araguaia)", Disponível em: http://www.corteidh.or.cr/docs/supervisiones/gomes_17_10_14_por.pdf. Acesso em: 04 nov. 2016.

${ }^{70}$ LASCALA, Maria Carolina Florentino; FREITAS, Riva Sobrado de. O Brasil e a Cooperação Jurídica com a Corte Interamericana de Direitos Humanos. Direitos Fundamentais e Justiça. Ano 6, n. 18, p. 97-119, jan.-mar. 2012. Disponível em: http://www.dfj.inf.br/Arquivos/PDF_Livre/18_Dout_Nacional\%201.pdf. Acesso em: 04 nov. 2016.

${ }^{71}$ CORTE INTERAMERICANA DE DIREITOS HUMĀNOS. Supervisão de Cumprimento de Sentença caso "Gomes Lund e outros (Guerrilha do Araguaia)", Disponível em: http://www.corteidh.or.cr/docs/supervisiones/gomes_17_10_14_por.pdf. Acesso em: 04 nov. 2016. 
Outrossim, todas as sentenças julgadas pela Corte Interamericana de Direitos Humanos em desfavor do Estado brasileiro causaram repercussão no âmbito interno do país, algumas de forma mais visível, outras de modo mais discreto, mas não menos importante.

O caso "Ximenes Lopes" produziu diversos efeitos positivos no país, dentre eles a possibilidade de despertar a sociedade, tanto em âmbito interno, quanto internacionalmente, para o tratamento oferecido aos sujeitos acometidos por transtornos mentais nos estabelecimentos de tratamento psiquiátricos, impondo ao Estado brasileiro a adoção de reformas em matéria de saúde mental ${ }^{72}$. À vista disso, dentre as inovações mais importantes para reformular a Política Nacional de Saúde Mental, sancionou-se a Lei no $10.216 / 2001^{73}$, que "dispõe sobre a proteção e os direitos das pessoas portadoras de transtornos mentais e redireciona o modelo assistencial em saúde mental", "responsabilizando o Estado e, também, a sociedade pela superação do modelo assistencial até então vigente baseado, exclusivamente, na internação tradicional"74. Importante ressaltar que, embora a Lei seja do ano de 2001 e a sentença do ano de 2006, o caso "Ximenes Lopes" já havia sido proposto junto à Corte no ano de 1999, o que permite concluir que a denunciação pela Comissão Interamericana colaborou eficazmente para agilizar o processo de aprovação da Lei ${ }^{75}$.

${ }^{72} \mathrm{CEIA}$, Eleonora Mesquita. A Jurisprudência da Corte Interamericana de Direitos Humanos e o Desenvolvimento da Proteção dos Direitos Humanos no Brasil. EMERJ, Rio de Janeiro, v. 16, n. 61, p. 113-152, jan.-fev.-mar. 2013.2 Disponível em: http://www.emerj.tjij.jus.br/revistaemerj_online/edicoes/revista61/revista61_113.pdf. Acesso em: 04 nov. 2016.

73BRASIL. Lei n. 10.216, de 6 de abril de 2001. Dispõe sobre a proteção e os direitos das pessoas portadoras de transtornos mentais e redireciona o modelo assistencial em saúde mental. Disponível em: http://www.planalto.gov.br/ccivil_03/leis/LEIS_2001/L10216.htm. Acesso em: 04 nov. 2016.

${ }^{74}$ ROSATO, Cássia Maria; CORREIA, Ludmila Cerqueira. Caso Damião Ximenes Lopes: Mudanças e desafios após a primeira condenação do Brasil pela Corte Interamericana de Direitos Humanos. Conectas Direitos Humanos. v. 8, n. 15, jan/2011. Disponível em: http://www.conectas.org/pt/acoes/sur/edicao/15/1000169-caso-damiao-ximenes-lopes-mudancas-edesafios-apos-a-primeira-condenacao-do-brasil-pela-corte-interamericana-de-direitos-humanos. Acesso em: 04 nov. 2016.

${ }^{75} \mathrm{Ibidem}$. 
Com o julgamento do caso "Escher e outros" pela Corte Interamericana de Direitos Humanos, não foi possível perceber repercussão interna no que tange a alterações legislativas ou qualquer inovação no âmbito das políticas públicas. Possivelmente, tal situação tenha se dado pelo fato de que a Constituição Federal da República Brasileira já trata de garantir a inviolabilidade das comunicações. Efetivamente, a colaboração da sentença foi para direcionar a população brasileira quanto aos excessos na atuação dos agentes públicos quando da aplicação da Lei $n^{\circ}$ 9.296/96, que prevê a possibilidade de interceptar e monitorar comunicações, a fim de suprimir o crime, mas que acabava sendo utilizada de maneira imoderada, transformando-se em um mecanismo para perseguição e espionagem ${ }^{76}$.

Assim como no item anterior, o caso "Garibaldi" contribuiu internamente para o Estado brasileiro no sentido de chamar a atenção da sociedade brasileira em geral, sobretudo da imprensa e autoridades, para os casos de violações de direitos humanos na esfera doméstica, haja vista que tal situação demonstra a desigualdade social dos grupos vulneráveis, bem assim o hábito relativo à violência e falta de punição que, infelizmente, estão ainda muito presentes no dia a dia brasileiro ${ }^{77}$.

A sentença proferida no caso "Gomes Lund e outros (Guerrilha do Araguaia)" trouxe repercussões importantes para o país, principalmente no que diz respeito ao ressarcimento e à memoração das vítimas que tiveram os seus direitos humanos violados no período ditatorial. Com efeito, mesmo antes da publicação da sentença do caso, o Brasil já havia adotado providências para admitir sua responsabilidade, mesmo que em âmbito apenas interno, quanto às vítimas do regime militar, até mesmo as do caso "Guerrilha do Araguaia", ora tratado. Ressalta-se, pois, a Lei ำ 9.140/95 que "reconhece como mortas pessoas desaparecidas em razão de participação, ou acusação de participação, em atividades políticas, no período de 2 de setembro de

\footnotetext{
${ }^{76} \mathrm{CEIA}$, op. cit.

${ }^{77} \mathrm{CEI}$, Eleonora Mesquita. A Jurisprudência da Corte Interamericana de Direitos Humanos e o Desenvolvimento da Proteção dos Direitos Humanos no Brasil. EMERJ, Rio de Janeiro, v. 16, n. 61, p. 113-152, jan.-fev.-mar. 2013.2 Disponível em: http://www.emerj.tjrj.jus.br/revistaemerj_online/edicoes/revista61/revista61_113.pdf. Acesso em: 04 nov. 2016.
} 
1961 a 15 de agosto de 1979, e dá outras providências". Ademais, o art. 4ํ da mesma Lei tratou de criar a Comissão Especial sobre Mortos e Desaparecidos Políticos, a qual possui como objetivo encontrar os restos mortais dos sujeitos desaparecidos, confirmá-los como vítimas e, de acordo com o caso, aprovar a reparação pecuniária. Outrossim, no ano de 2006 criou-se um reservatório de amostra de DNA dos familiares das vítimas, a fim de auxiliar a identificação quando localizado algum resto mortal. Ainda, a sentença do caso motivou os agentes públicos a empregar maior esforço na investigação e, dependendo do caso, reparação das violações praticadas à época da ditadura militar. Nesse passo, foi sancionada a Lei $n 012.528 / 2011$, que "cria a Comissão Nacional da Verdade no âmbito da Casa Civil da Presidência da República", cuja finalidade é averiguar e elucidar as graves violações dos direitos humanos praticadas no período compreendido entre os anos de 1946 a 1988. Outra ação, também, foi a aprovação da Lei no 12.527/2011 - Lei de Acesso a Informações Públicas -, que aprimora e fortifica o marco normativo do direito de liberdade de pensamento e expressão ${ }^{78}$.

\subsection{Propostas para agilizar a execução das sentenças internacionais no Brasil}

Conforme já tratado no presente escrito acadêmico, caso o Estado brasileiro seja considerado violador de direitos humanos e, portanto, condenado pela Corte Interamericana de Direitos Humanos, deverá adotar mecanismos do seu ordenamento jurídico interno para o fim de efetivar todas as determinações impostas nas sentenças, as quais podem prever os mais diferentes tipos de reparação. Nesse passo, de maneira geral, a execução das decisões pode se dar de dois modos, quais sejam: por meio de cumprimento espontâneo pelo país ou através de execução forçada, que se dará por intermédio do Poder Judiciário ${ }^{79}$.

\footnotetext{
${ }^{78}$ |bidem.

${ }^{79} \mathrm{COELHO}$, Rodrigo Meirelles Gaspar. Direitos Humanos na OEA e a busca pela eficácia das sentenças da Corte Interamericana. Disponível em: http://www.egov.ufsc.br/portal/sites/default/files/anexos/22436-22438-1-PB.pdf. Acesso em: 04 nov. 2016.
} 
Rodrigo Meirelles Gaspar Coelho explica que:

\begin{abstract}
Apenas os Poderes Executivo e Legislativo têm os meios necessários para executar espontaneamente as sentenças da Corte Interamericana. O Poder Judiciário, em razão de sua natureza, deve ser acionado para participar da execução das decisões internacionais. Em caso de inércia ou demora injustificada do Estado, poderá haver a implementação forçada das sentenças da Corte Interamericana, porque o Poder Judiciário poderá ser acionado pela vítima, seu representante legal ou pelo Ministério Público ${ }^{80}$.
\end{abstract}

Sem sombra de dúvidas, a execução espontânea pelo Estado é a forma mais rápida e eficaz de cumprir com as determinações impostas nas sentenças internacionais. No entanto, caso as decisões não sejam executadas de forma voluntária, o Poder Judiciário poderá ser acionado para que ocorra a implementação forçada.

Com relação às determinações impostas nas sentenças internacionais para indenizações pecuniárias, o artigo 68.2 da Convenção Americana de Direitos Humanos informa que "a parte da sentença que determinar indenização compensatória poderá ser executada no país respectivo pelo processo interno vigente para a execução de sentenças contra o Estado"81. De outra banda, quanto às sentenças que determinam obrigações diversas das pecuniárias, como as de fazer e não fazer, o artigo 2 da Convenção dispôs apenas que os Estados devem adotar medidas legislativas ou de outra natureza que efetivem os direitos e liberdades garantidos na Convenção ${ }^{82}$. Ocorre que, muito embora os dizeres da Convenção Americana, o Estado brasileiro não possui um método determinado ou uma legislação específica capaz de honrar com as disposições das sentenças proferidas pela Corte, o que demonstra quão importante é estudar sobre as formas de cumprimento das decisões internacionais.

\footnotetext{
80lbidem.

${ }^{81}$ ORGANIZAÇÃO DOS ESTADOS AMERICANOS. Convenção Americana de Direitos Humanos. Disponível em: https://www.cidh.oas.org/basicos/portugues/c.convencao_americana.htm. Acesso em: 04 nov. 2016.

82ORGANIZAÇÃO DOS ESTADOS AMERICANOS. Convenção Americana de Direitos Humanos. Disponível em: https://www.cidh.oas.org/basicos/portugues/c.convencao_americana.htm. Acesso em: 04 nov. 2016.
} 
Pois bem, uma das alternativas encontradas, nesse caso para efetivar as condenações de cunho pecuniário, é a de o Estado brasileiro obedecer à forma prescrita no artigo 100, da Constituição Federal, que determina que os pagamentos sejam realizados por meio do sistema de precatórios, em ordem cronológica83. Não obstante, a morosidade desse sistema é fato notório no país, situação que acabaria por prejudicar ainda mais as partes, que esperam por uma reparação além de justa, célere. De fato, a demora existente e deveras conhecida para o pagamento dos precatórios pode vir a implicar, inclusive, em um descumprimento da sentença internacional pelo Estado brasileiro. De outro vértice, depois da primeira sentença proferida em desfavor do Brasil, no caso "Ximenes Lopes”, o Estado passou a antever orçamento com destinação de quantia para o pagamento das indenizações pecuniárias prescritas pela Corte ${ }^{84}$, situação que de certa forma vem viabilizando o cumprimento dessa espécie de determinação imposta nas sentenças internacionais e que pode continuar servindo como uma alternativa momentânea, a fim de evitar o moroso sistema de precatórios. Apesar disso, as reparações de cunho financeiro podem ser executadas de forma um tanto quanto simples pelo Estado, bastando apenas um compromisso mais leal do país em relação a Corte e os princípios norteadores do direito internacional ${ }^{85}$. Para tanto, faz-se necessário uma evolução no que tange ao desenvolvimento e conhecimento do direito internacional em âmbito interno, seja através de uma maior observância da jurisprudência da Corte Interamericana nos julgados do STF, que pouco se destaca, seja pela promoção da cultura da proteção dos direitos humanos junto à sociedade civil, tendo em vista que um maior conhecimento em relação ao tema resultaria em uma pressão social nas

83BRASIL. Constituição (1988). Constituição da República Federativa do Brasil. Disponível em: http://www.planalto.gov.br/ccivil_03/constituicao/constituicaocompilado.htm. Acesso em: 04 nov. 2016.

${ }^{84}$ LASCALA, Maria Carolina Florentino; FREITAS, Riva Sobrado de. O Brasil e a Cooperação Jurídica Internacional com a Corte Interamericana de Direitos Humanos. DIREITOS FUNDAMENTAIS \& JUSTIÇA - Ano 6, n. 18, p. 97-119, jan./mar. 2012. Disponível em: http://www.dfj.inf.br/Arquivos/PDF_Livre/18_Dout_Nacional\%201.pdf. Acesso em: 04 nov. 2016.

${ }^{85}$ PAIXÃO, Cristiano; FRISSO, Giovana; SILVA, Janaína Lima Penalva da. Caso Ximenes Lopes versus Brasil - Corte Interamericana de Direitos Humanos* Relato e Reconstrução Jurisprudencial. Disponível em: http://direitosp.fgv.br/sites/direitosp.fgv.br/files/narrativa_final_ximenes.pdf. Acesso em: 04 nov. 2016. 
autoridades acerca dos casos de violação aos direitos humanos e, portanto, para o cumprimento célere e efetivo das sentenças internacionais ${ }^{86}$.

Contudo, depois de realizada a análise do cumprimento de todas as sentenças proferidas pela Corte Interamericana de Direitos Humanos em face do Brasil, foi possível perceber que as obrigações que não envolvem pagamento de indenizações pecuniárias são as que apresentam maior problemática, já que são as menos executadas pelo Estado, sobretudo pelo desconhecimento das autoridades quanto aos procedimentos a serem tomados nos casos em que, por exemplo, devem ser adotadas medidas de políticas públicas para proteção dos direitos humanos ou quando necessária investigação dos fatos que ensejaram a violação aos direitos humanos e à Convenção Americana.

Dito isso, como forma de "compelir" o Estado brasileiro a agir com celeridade e eficácia no cumprimento de todos os pontos das decisões emanadas pela Corte Interamericana (cunho pecuniário e obrigações de fazer ou não fazer), mostra-se relevante uma maior divulgação, tanto em âmbito interno quanto internacional, dos casos de violações aos direitos humanos praticados, tendo em vista que tal ação acabaria por intimidar e pressionar político e moralmente o país, inclusive na comunidade internacional, para que apresente justificativas e condutas positivas para a reparação de sua prática ${ }^{87}$. Ademais, a Convenção Americana de Direitos Humanos é omissa ao deixar de indicar um mecanismo preciso para controlar o cumprimento das decisões proferidas pela Corte Interamericana, ou seja, são os próprios órgãos integrantes do Sistema Interamericano que acompanham os procedimentos adotados pelos Estados quanto às determinações impostas nas sentenças por eles proferidas ${ }^{88}$. Logo, a observância e extinção dessa lacuna, com a criação de um órgão de controle

${ }^{86} \mathrm{CEIA}$, Eleonora Mesquita. A Jurisprudência da Corte Interamericana de Direitos Humanos e o Desenvolvimento da Proteção dos Direitos Humanos no Brasil. EMERJ, Rio de Janeiro, v. 16, n. 61, p. 113-152, jan.-fev.-mar. 2013.2 Disponível em: http://www.emerj.tjrj.jus.br/revistaemerj_online/edicoes/revista61/revista61_113.pdf. Acesso em: 04 nov. 2016.

${ }^{87}$ PIOVESAN, Flávia. Temas de Direitos Humanos. 4. ed. São Paulo: Saraiva, 2010. p. 96. ${ }^{88}$ Ibidem, p. 99. 
específico, contribuiriam de maneira produtiva na eficácia das sentenças emitidas pelo órgão jurisdicional internacional.

Não obstante tais observações, considerando que o Estado brasileiro não possui uma legislação específica que cuide de disciplinar o modo como devem ser cumpridas todas as espécies de determinações impostas nas sentenças internacionais, a promulgação dessa norma far-se-ia extremamente relevante, principalmente pelo notório excesso de burocracia existente no país. Desse modo, poderiam ser esclarecidas todas as dúvidas relativas à forma de cumprimento das obrigações pelo Estado condenado, notadamente o Estado brasileiro, bem assim sobre a quem incumbiria supervisionar e organizar esse procedimento em âmbito interno ${ }^{89}$. Flávia Piovesan apresenta uma proposta nesse sentido: [...] "a adoção pelos Estados de legislação relativa à implementação das decisões internacionais em matéria de direitos humanos"90. Com efeito, somente a criação de um mecanismo interno específico será capaz de honrar com as disposições internacionais e, assim, dar cumprimento integral a todas as medidas impostas nas sentenças proferidas pela Corte Interamericana de Direitos Humanos em face do Estado brasileiro.

Importa referir, nesse sentido, a existência do Projeto de Lei n. 4.667-C/200491, que atualmente tramita junto ao Senado Federal sob o n. 170/2011, e que dispõe sobre a forma de cumprimento das decisões proferidas pelos Organismos Internacionais de Proteção aos Direitos Humanos. Ressalta-se que a redação dos projetos anteriormente apresentados e já arquivados não tratava de todas as formas de obrigações que comumente estão inseridas nas decisões da Corte Interamericana. Por essa razão, o Deputado relator da Comissão de Direitos Humanos e Minorias,

\footnotetext{
89LASCALA, Maria Carolina Florentino; FREITAS, Riva Sobrado de. O Brasil e a Cooperação Jurídica Internacional com a Corte Interamericana de Direitos Humanos. DIREITOS FUNDAMENTAIS \& JUSTIÇA - Ano 6, n. 18, p. 97-119, jan./mar. 2012. Disponível em: http://www.dfj.inf.br/Arquivos/PDF_Livre/18_Dout_Nacional\%201.pdf. Acesso em: 04 nov. 2016.

90PIOVESAN, Flávia. Temas de Direitos Humanos. 4. ed. São Paulo: Saraiva, 2010. p. 100.

${ }^{91}$ BRASIL. Congresso. Câmara. Projeto de lei da Câmara dos Deputados n4.667-D de 2004. Dispõe sobre os efeitos jurídicos das decisões dos Organismos Internacionais de Proteção aos Direitos Humanos e dá outras providências. Disponível em: http://www.camara.gov.br/proposicoesWeb/prop_mostrarintegra;jsessionid=9CA2040112FCBC9C3 $941 \mathrm{AC} 77265439 \mathrm{~F} 7$. node2 ?codteor $=528706 \&$ filename $=$ Avulso+-PL+4667/2004. Acesso em: 09 nov . 2016.
} 
Orlando Fantazzini, apresentou uma emenda substitutiva derivada de diversos debates realizados junto à comunidade jurídica operante na área dos direitos humanos ${ }^{92}$.

Entre as mais importantes inovações podem ser citadas as constantes nos artigos $4^{\circ}$ e 5ํำ do Projeto, as quais se referem à constituição de um órgão responsável por conduzir a forma de cumprimento das decisões emanadas pelos Organismos Internacionais de Proteção aos Direitos Humanos, através de um representante da sociedade civil e outro representante interministerial, bem como a obrigação desse órgão em notificar os responsáveis para que seja dado cumprimento às obrigações previstas nas sentenças proferidas. Ademais, como outra novidade, o Projeto informa sobre a cooperação da sociedade em geral no processo de cumprimento das decisões internacionais e na identificação das providencias necessárias à implementação das sentenças ${ }^{93}$.

Não obstante a importância das medidas elencadas para o cumprimento das decisões proferidas pela Corte Interamericana, a referida emenda foi rejeitada pela Comissão de Constituição, Justiça e Cidadania, sob a alegação de que ela ofendia a soberania do Estado em oposição com a Constituição Federal. Nesse passo, a redação do Projeto que seguiu para apreciação do Senado Federal é similar à proposta original, permanecendo, mesmo que aprovado, os problemas existentes quanto à implementação, em âmbito interno, das sentenças que determinam obrigações de fazer, visto que continuam sendo tratadas apenas das indenizações de cunho pecuniário ${ }^{94}$.

\section{CONSIDERAÇÕES FINAIS}

\footnotetext{
${ }^{92}$ COIMBRA, Elisa Mara. Sistema Interamericano de Direitos Humanos: Desafios à implementação das decisões da Corte no Brasil. CONECTAS DIREITOS HUMANOS - Ed. vol. 10 - n. 19 - dez/2013. Disponível em: http://www.conectas.org/pt/acoes/sur/edicao/19/1000457-sistema-interamericano-dedireitos-humanos-desafios-a-implementacao-das-decisoes-da-corte-no-brasil. Acesso em 08 nov. 2016.

93lbidem.

${ }^{94}$ Ibidem.
} 
O presente trabalho se propôs, como objetivo geral, a realizar uma análise acerca do cumprimento das decisões emanadas pela Corte Interamericana de Direitos Humanos no Estado brasileiro, sendo examinados, para tanto, todos os quatro casos julgados em desfavor do país, assim como a postura da Administração Pública diante das condenações. Para isto, foi analisada a legitimidade das decisões proferidas pela Corte, tendo em vista a sujeição voluntária do Estado brasileiro à sua jurisdição, tal como o conceito de soberania que rege as relações internacionais.

Conforme visto no presente escrito acadêmico, o Estado brasileiro reconheceu voluntariamente a competência contenciosa da Corte Interamericana de Direitos Humanos através do Decreto Legislativo no 89, do ano de 1998. Portanto, a partir desse reconhecimento o país já poderia ser demandado perante a Corte nos casos em que evidenciada possível violação de direitos humanos, haja vista a legitimidade das decisões proferidas pelo órgão, as quais são definitivas, inapeláveis e possuem caráter obrigatório, nos termos do art. 68.1 da Convenção Americana de Direitos Humanos.

Desde a data em que o Brasil, enquanto estado soberano, reconheceu a competência contenciosa da Corte Interamericana de Direitos Humanos, já foram proferidas quatro condenações em seu desfavor, sendo a primeira do ano de 2006, no caso "Ximenes Lopes", a segunda de 2009, no caso "Escher e outros", a terceira também do ano de 2009, no caso "Garibaldi”, e a última de 2010, no caso "Gomes Lund e outros (Guerrilha do Araguaia)". Dentre as espécies de determinações impostas nas decisões possível destacar as de obrigação de fazer e as de caráter indenizatório. Outrossim, mesmo sendo a primeira condenação datada de 2006, o Estado brasileiro somente logrou êxito em cumprir todas as determinações impostas na sentença do caso "Escher e outros", que foi arquivado no ano de 2012. As demais decisões ainda encontram-se pendentes de cumprimento, ainda que parcialmente, tendo sido possível perceber que o Brasil possui maior dificuldade em cumprir as obrigações de investigar e, se for o caso, punir os responsáveis pela violação dos direitos humanos ocorridas em cada caso, através da aplicação do direito interno. 
De fato, algumas especificidades do Estado brasileiro constituem obstáculos ao cumprimento das decisões internacionais, entre elas, a desorganização da administração pública e a falta de conhecimento das autoridades governamentais a respeito na natureza jurídica das decisões da Corte Interamericana de direitos Humanos. Contudo, embora não exista previsão legal no Brasil sobre a execução das decisões proferidas pela Corte, isso não significa que o país poderá descumprir as medidas que lhe foram impostas.

Destarte, dentre as alternativas referidas no presente trabalho, conclui-se que, para honrar com o cumprimento de todas as medidas impostas nas sentenças internacionais pela Corte Interamericana de Direitos Humanos em face do Estado brasileiro, de maneira justa e célere, a criação de uma legislação específica capaz de determinar a forma de execução das sentenças internacionais em âmbito interno, bem como que disponha acerca dos responsáveis pelos procedimentos de organizar e supervisionar referido procedimento mostra-se extremamente relevante $\mathrm{e}$ imprescindível, como forma de concretizar verdadeiramente a justiça em todos os casos em que comprovada à violação aos direitos humanos e à Convenção Americana.

\section{REFERÊNCIAS}

ACCIOLY, Hildebrando; SILVA, G. E. do Nascimento E; CASELLA, Paulo Borba. Manual de Direito Internacional Público. 18. ed. São Paulo: Saraiva, 2010.

AMARAL JUNIOR, Alberto do. Curso de Direito Internacional Público. 4. ed. São Paulo: Atlas S.A, 2013.

AMARAL, Renata Campetti. Direito Internacional Público e Privado. 6. ed. Porto Alegre: Verbo Jurídico, 2010.

BRASIL. Congresso. Câmara. Projeto de lei da Câmara dos Deputados n4.667-D de 2004. Dispõe sobre os efeitos jurídicos das decisões dos Organismos Internacionais de Proteção aos Direitos Humanos e dá outras providências. Disponível em: http://www.camara.gov.br/proposicoesWeb/prop_mostrarintegra;jsessionid=9CA2040 
112FCBC9C3941AC77265439F7.node2?codteor=528706\&filename=Avulso+PL+4667/2004. Acesso em: 09 nov. 2016.

BRASIL. Constituição (1988). Constituição da República Federativa do Brasil. Disponível em:

http://www.planalto.gov.br/ccivil_03/constituicao/constituicaocompilado.htm. Acesso em: 04 nov. 2016.

BRASIL. Decreto n. 89, de 3 de dezembro de 1998. Aprova a solicitação de reconhecimento da competência obrigatória da Corte Interamericana de Direitos Humanos em todos os casos relativos à interpretação ou aplicação da Convenção Americana de Direitos Humanos para fatos ocorridos a partir do reconhecimento, de acordo com o previsto no parágrafo primeiro do art. 62 daquele instrumento internacional. Disponível em:

http://www2.camara.leg.br/legin/fed/decleg/1998/decretolegislativo-89-3-dezembro1998-369634-publicacaooriginal-1-pl.html. Acesso em: 04 nov. 2016.

BRASIL. Lei n. 10.216, de 6 de abril de 2001.

Dispõe sobre a proteção e os direitos das pessoas portadoras de transtornos mentais e redireciona o modelo assistencial em saúde mental. Disponível em: http://www.planalto.gov.br/ccivil_03/leis/LEIS_2001/L10216.htm. Acesso em: 04 nov. 2016.

CEIA, Eleonora Mesquita. A Jurisprudência da Corte Interamericana de Direitos Humanos e o Desenvolvimento da Proteção dos Direitos Humanos no Brasil.

EMERJ, Rio de Janeiro, v. 16, n. 61, p. 113-152, jan.-fev.-mar. 2013. Disponível em: http://www.emerj.tjrj.jus.br/revistaemerj_online/edicoes/revista61/revista61_113.pdf. Acesso em: 04 nov. 2016.

COELHO, Rodrigo Meirelles Gaspar. Direitos Humanos na OEA e a busca pela eficácia das sentenças da Corte Interamericana. Disponível em: http://www.egov.ufsc.br/portal/sites/default/files/anexos/22436-22438-1-PB.pdf. Acesso em: 04 nov. 2016.

COIMBRA, Elisa Mara. Sistema Interamericano de Direitos Humanos: Desafios à implementação das decisões da Corte no Brasil. CONECTAS DIREITOS HUMANOS - Ed. vol. 10 - n. 19 - dez/2013. Disponível em:

http://www.conectas.org/pt/acoes/sur/edicao/19/1000457-sistema-interamericano-dedireitos-humanos-desafios-a-implementacao-das-decisoes-da-corte-no-brasil. Acesso em 08 nov. 2016.

CORTE INTERAMERICANA DE DIREITOS HUMANOS. Dados técnicos caso "Escher e outros". Disponível em: 
http://www.corteidh.or.cr/cf/Jurisprudencia2/ficha_tecnica.cfm?nld_Ficha=277\&lang= en. Acesso em: 04 nov. 2016.

CORTE INTERAMERICANA DE DIREITOS HUMANOS. Dados técnicos caso "Garibaldi". Disponível em:

http://www.corteidh.or.cr/cf/Jurisprudencia2/ficha_tecnica.cfm?nld_Ficha=282\&lang= en. Acesso em: 04 nov. 2016.

CORTE INTERAMERICANA DE DIREITOS HUMANOS. Dados técnicos caso "Gomes Lund e outros (Guerrilha do Araguaia)". Disponível em:

http://www.corteidh.or.cr/cf/Jurisprudencia2/ficha_tecnica.cfm?nld_Ficha=342\&lang= en. Acesso em: 04 nov. 2016.

CORTE INTERAMERICANA DE DIREITOS HUMANOS. Dados técnicos caso "Ximenes Lopes": Disponível em:

http://www.corteidh.or.cr/cf/Jurisprudencia2/ficha_tecnica.cfm?nld_Ficha=319\&lang= en. Acesso em: 04 nov. 2016.

CORTE INTERAMERICANA DE DIREITOS HUMANOS. Decisões e Julgamentos. Disponível em: http://www.corteidh.or.cr/cf/Jurisprudencia2/index.cfm?lang=en.

Acesso em: 04 nov. 2016.

CORTE INTERAMERICANA DE DIREITOS HUMANOS. Monitoramente Cumprimento de Sentença. Disponível em:

http://www.corteidh.or.cr/cf/Jurisprudencia2/busqueda_supervision_cumplimiento.cfm ?lang=en. Acesso em: 04 nov. 2016.

CORTE INTERAMERICANA DE DIREITOS HUMANOS. Regulamento da Corte Interamericana de Direitos Humanos. Disponível em:

https://www.cidh.oas.org/basicos/portugues/Viejos/w.Regulamento.Corte.htm.

Acesso em: 04 nov. 2016.

CORTE INTERAMERICANA DE DIREITOS HUMANOS. Sentença caso "Damião Ximenes Lopes". Disponível em:

http://www.corteidh.or.cr/docs/casos/articulos/seriec_149_por.pdf. Acesso em: 04 nov. 2016.

CORTE INTERAMERICANA DE DIREITOS HUMANOS. Sentença caso "Escher e outros". Disponível em:

http://www.corteidh.or.cr/docs/casos/articulos/seriec_200_por.pdf. Acesso em: 04 nov. 2016.

CORTE INTERAMERICANA DE DIREITOS HUMANOS. Sentença caso

"Garibaldi". Disponível em: 
http://www.corteidh.or.cr/docs/casos/articulos/seriec_203_por.pdf. Acesso em: 04 nov. 2016.

CORTE INTERAMERICANA DE DIREITOS HUMANOS. Sentença caso "Gomes Lund e outros (Guerrilha do Araguaia)". Disponível em:

http://www.corteidh.or.cr/docs/casos/articulos/seriec_219_por.pdf. Acesso em: 04 nov. 2016

CORTE INTERAMERICANA DE DIREITOS HUMANOS. Supervisão de Cumprimento de Sentença caso "Ximenes Lopes". Disponível em: http://www.corteidh.or.cr/docs/supervisiones/ximenes_17_05_10_\%20por.pdf. Acesso em: 04 nov. 2016.

CORTE INTERAMERICANA DE DIREITOS HUMANOS. Supervisão de Cumprimento de Sentença caso "Escher e outros". Disponível em: http://www.corteidh.or.cr/docs/supervisiones/escher_19_06_12_por.pdf. Acesso em: 04 nov. 2016.

CORTE INTERAMERICANA DE DIREITOS HUMANOS. Supervisão de Cumprimento de Sentença caso "Garibaldi”. Disponível em:

http://www.corteidh.or.cr/docs/supervisiones/garibaldi_20_02_12_por.pdf. Acesso em: 04 nov. 2016.

CORTE INTERAMERICANA DE DIREITOS HUMANOS. Supervisão de Cumprimento de Sentença caso "Gomes Lund e outros (Guerrilha do Araguaia)", Disponível em:

http://www.corteidh.or.cr/docs/supervisiones/gomes_17_10_14_por.pdf. Acesso em: 04 nov. 2016.

CULLETON, Alfredo; BRAGATO, Fernanda Frizzo; FAJARDO, Sinara Porto. Curso de Direitos Humanos. São Leopoldo: Unissinos, 2009.

GORCZEVSKI, Clovis; LEAL, Mônia Clarissa Heninng. Constitucionalismo Contemporâneo: Desafios e Perspectivas. Curitiba: Multideia, 2012.

LASCALA, Maria Carolina Florentino; FREITAS, Riva Sobrado de. O Brasil e a Cooperação Jurídica com a Corte Interamericana de Direitos Humanos. Direitos Fundamentais e Justiça. Ano 6, n. 18, p. 97-119, jan.-mar. 2012. Disponível em: http://www.dfj.inf.br/Arquivos/PDF_Livre/18_Dout_Nacional\%201.pdf. Acesso em: 04 nov. 2016.

MAZZUOLI, Valério de Oliveira. Curso de Direito Internacional Público. 5. ed. rev., atual. e ampl. São Paulo: Revista dos Tribunais, 2011. 
ORGANIZAÇÃO DOS ESTADOS AMERICANOS. Carta da Organização dos

Estados Americanos. Disponível em: http://www.oas.org/dil/port/tratados_A41_Carta_da_Organiza\%C3\%A7\%C3\%A3o_dos_Estados_Americanos.htm. Acesso em: 04 nov. 2016.

ORGANIZAÇÃO DOS ESTADOS AMERICANOS. Convenção Americana de Direitos Humanos. Disponível em:

https://www.cidh.oas.org/basicos/portugues/c.convencao_americana.htm. Acesso em: 04 nov. 2016.

PAIXÃO, Cristiano; FRISSO, Giovana; SILVA, Janaína Lima Penalva da. Caso Ximenes Lopes versus Brasil - Corte Interamericana de Direitos Humanos* Relato e Reconstrução Jurisprudencial. Disponível em:

http://direitosp.fgv.br/sites/direitosp.fgv.br/files/narrativa_final___ximenes.pdf. Acesso em: 04 nov. 2016.

PIOVESAN, Flávia. Direitos humanos e o direito constitucional internacional. 11. ed. rev. e atual. São Paulo: Saraiva, 2010.

PIOVESAN, Flávia. Temas de Direitos Humanos. 4. ed. São Paulo: Saraiva, 2010.

ROSATO, Cássia Maria; CORREIA, Ludmila Cerqueira. Caso Damião Ximenes Lopes: Mudanças e desafios após a primeira condenação do Brasil pela Corte Interamericana de Direitos Humanos. Conectas Direitos Humanos. v. 8, n. 15, jan/2011. Disponível em: http://www.conectas.org/pt/acoes/sur/edicao/15/1000169caso-damiao-ximenes-lopes-mudancas-e-desafios-apos-a-primeira-condenacao-dobrasil-pela-corte-interamericana-de-direitos-humanos. Acesso em: 04 nov. 2016.

WENDPAP, Friedmann; Kolotelo, Rosane. Direito Internacional. Rio de Janeiro: Elsevier, 2007. 